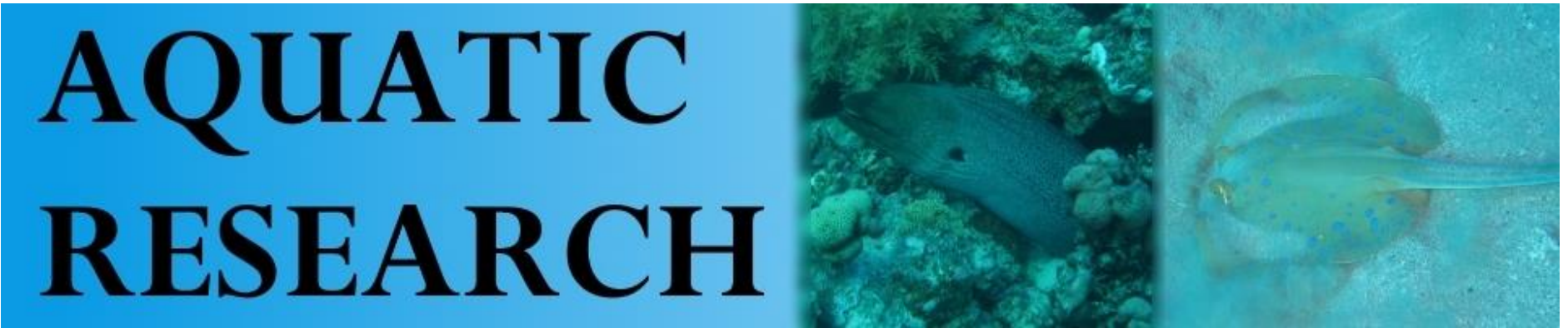

\title{
SPATIAL AND TEMPORAL DISTRIBUTION OF MARINE CLADOCERAN SPECIES IN THE SURFACE WATERS OF ISKENDERUN BAY
}

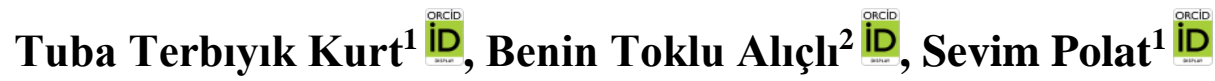

\section{Cite this article as:}

Terbıyık Kurt, T., Toklu Alıçl, B., Polat, S. (2018). A Spatial and Temporal Distribution of Marine Cladoceran Species in the Surface Waters of Iskenderun Bay. Aquatic Research, 1(2), 77-85. DOI: 10.3153/AR18009

${ }^{1}$ Çukurova University, Faculty of Fisheries, Department of Marine Sciences, 01330, Sarıçam, Adana, Turkey

2 Istanbul University, Faculty of Science, Department of Biology 34134, Vezneciler/İstanbul, Turkey.

Submitted: 06.02.2018

Accepted: 02.03.2018

Published online: 05.03.2018

Correspondence:

Tuba TERBIYIK KURT

E-mail:

tterbiyik@cu.edu.tr

CCopyright 2018 by ScientificWebJournals Available online at

http://aquatres.scientificwebjournals.com

\begin{abstract}
Cladocerans are important member of pelagic ecosystem and they serve as good sources of food for fish and fish larvae during the warm periods. The aim of this study was to determine species composition of marine cladocerans and their temporal and spatial distribution in the surface waters of coastal and offshore waters of Iskenderun Bay. The study was conducted at the four stations in Iskenderun Bay between November 2005 and August 2006. The samples were collected horizontally with WP-2 net (200 mesh size). Six species of cladocerans (Penilia avirostris, Evadne spinifera, Pseudoevadne tergestina, Evadne nordmanni, Pleopis polyphamoides and Podon intermedius) were found. Among these, Evadne nordmanni was observed for the first time in Iskenderun Bay. With regard to annual abundance of cladoceran species, Evadne spinifera was the most abundant and followed by $P$. avirostris and $P$. tergestina. While the maximum abundance of cladoceran was observed in May-06, the minimum abundance was in November-05. It can be concluded that results of this study could provide a significant contribution to the future studies on cladoceran diversity in the region.
\end{abstract}

Keywords: Marine cladocerans, Iskenderun Bay, Abundance, Temporal distribution 


\section{Introduction}

Having nearly six hundred species, cladocerans are represented by eight species in marine environments (Onbè 1999). This group is distributed in nearly all oceans and seas of the world. Some of its members are distributed widely in open seas (Gieskes, 1971), while some are densely distributed in coastal areas (Sherman, 1966), especially in bights and bays with river inputs (Bosch and Taylor, 1968, 1973). They have an important role for carnivores which are in the higher level of food web and, thereby, make a significant contribution to the energy and matter cycles. Cladocerans are found less densely in unstratified waters. Their vertical distribution is limited with surface waters and they are densely found above $15 \mathrm{~m}$ (Tregouboff 1963). In addition, they need proper conditions in near-surface waters in order to reproduce and spread successfully (Moraitou-Apostolopoulou and Kiortsis 1973). Although they have an important place in food chain and show significant temporal changes in the plankton, there are not sufficient studies on the cladocerans in Turkish seas compared to other planktonic groups (Aker and Özel 2006; Büyükateş and İnanmaz 2007; Büyükateş and İnanmaz 2010, Terbıyık and Polat 2013, 2017). In the previous studies conducted in Iskenderun Bay, six cladoceran species were recorded (Dönmez 1998; Toklu and Sarıhan 2003; Toklu-Alıçlı and Sarıhan 2016; Terbiyık and Polat 2013, 2017). The abundance of cladocerans increases in spring and summer, and they comprise the great majority of zooplanktons in these periods (Terbiy1k Kurt and Polat, 2014). Majority of the studies conducted in the İskenderun Bay comprised only species composition (Toklu and Sarıhan 2003; Toklu-Alıçlı and Sarıhan 2016). There are few data available regarding the abundance changes in the species (Terbiylk Kurt and Polat, 2013, 2014, 2017). But these studies conducted in the areas very close to coast and sampling depth of the stations area changed 5 to $10 \mathrm{~m}$. Apart from previously conducted studies, present study comprise species diversity and relative abundance data in offshore areas as well as coastal areas of İskenderun Bay. The aim is to determine the species composition, distribution and abundance changes of cladocerans in the surface waters of İskenderun Bay.

\section{Materials and Methods}

\section{Study Area}

Iskenderun Bay is formed due to the recession of Eastern Mediterranean Sea on its northeastern corner into the Anatolia in the direction of southwest-northeast (Figure 1). It is $65 \mathrm{~km}$ length, and $35 \mathrm{~km}$ width, and has an area of approximately $2275 \mathrm{~km}^{2}$ and an average depth of $70 \mathrm{~m}$, and the greatest depth which is approximately $100 \mathrm{~m}$ is found at the entrance of the bay (Avşar 1999). The bay is affected much by bottom currents and winds since the width of the region where it is connected to the open sea is large (Iyiduvar 1986). The largest river which flows into Iskenderun Bay is the Ceyhan River. Its time-averaged flow rate is $180 \mathrm{~m}^{3} / \mathrm{sec}$. Due to all these factors, the bay has a hydrographically dynamic structure.

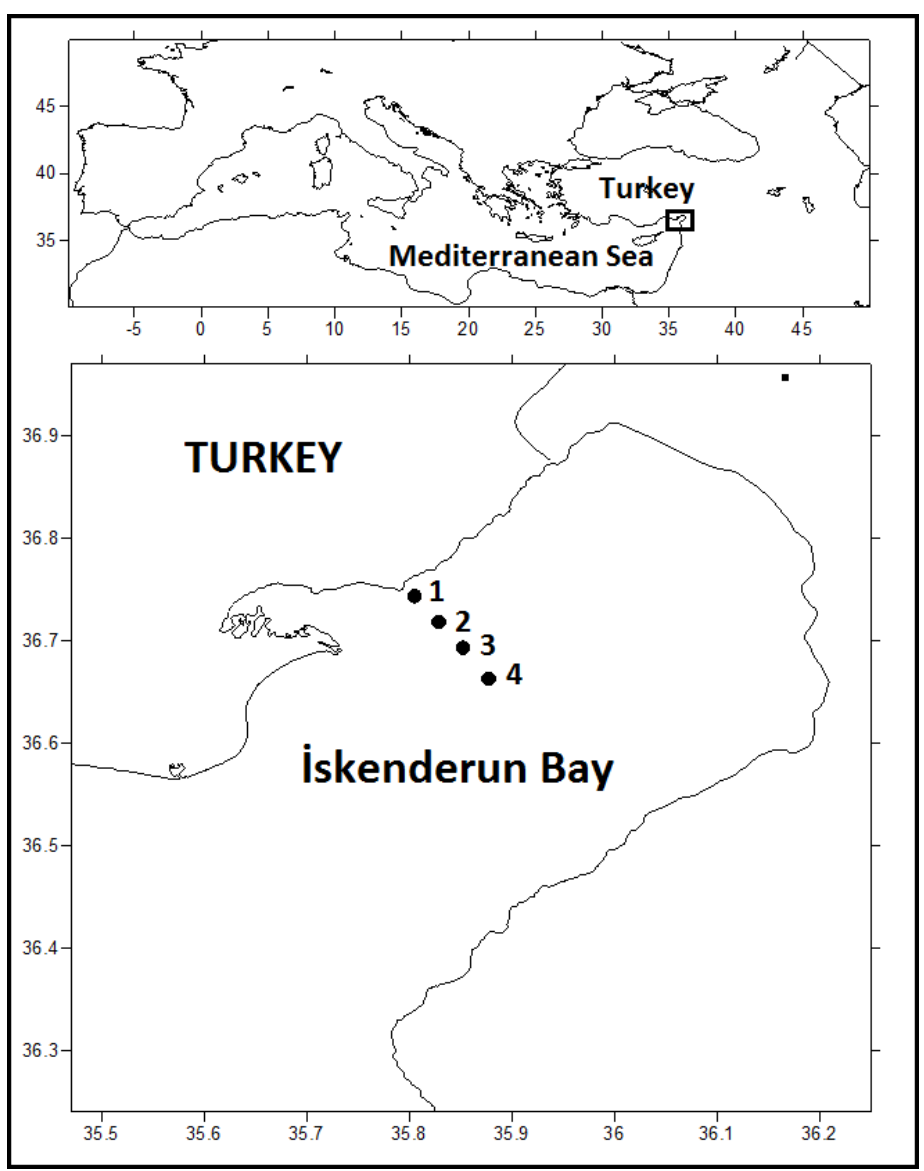

Figure 1. Study area and sampling stations

Methods

Samplings were conducted at four stations which were determined from the coast to offshore in Iskenderun Bay seasonally between November 2005 and July 2006 (Figure 1). Zooplankton samples were collected horizontally at each station using a WP-2 plankton net with a mouth area of 57 $\mathrm{cm}$ and mesh size of $200 \mu \mathrm{m}$. The samples were preserved in the $4 \%$ borax buffered formaldehyde-seawater solution. At every station, temperature and salinity data were measured using CTD probe. Sub-samples were taken with Stempel Pipette depending on the cladoceran density in the sample. Identification and counting were performed under the Olympus SZX16 stereomicroscope. The identification 
of cladoceran species was realized according to Onbè (1999). Cladoceran abundance was calculated on the basis of individual number per $\mathrm{m}^{3}$.

\section{Results and Discussion}

Seawater temperature and salinity were measured in the surface layer and the values were shown in Figure 2. Temperature showed significant temporal changes during the study. The lowest temperature values were recorded at near coastal stations (stations 1 and 2) in February- $06\left(15.7^{\circ} \mathrm{C}\right)$ and the highest at offshore station (station 4) in August-06 $\left(30.8^{\circ} \mathrm{C}\right)$. Salinity values were partially homogeneous and significantly lower values were measured at all stations only in November-05 compared to the other months (station 1, 35.5 $\mathrm{psu}$ ). These lower values were due to the rainy weather during the sampling period. On the other hand, the highest value was measured in February-06 (station 1, 38.7 psu).
In the study area, six cladoceran species which belong to five genera were recorded. These were P. avirostris, E.spinifera, $P$. tergestina, E. nordmanni, $P$. polyphemoides and $P$. intermedius. Among recorded species, E. spinifera was the dominant species in terms of abundance and followed by $P$. avirostris and $P$. tergestina, respectively. These three species comprised nearly $98 \%$ of cladoceran abundance (Figure 3). When temporal changes of the species was evaluated, $P$. avirostris were observed in all sampling times and E. spinifera and $P$. tergestina in February-06, May-06 and August-06, and P. intermedius in May-06 and August-06. On the other hand, E. nordmanni and $P$. polyphemoides were found only in February-06. Considering species abundance, E. spinifera was dominant in February-06 and May06 while P. tergestina was dominant in August-06 (Figure $4)$.

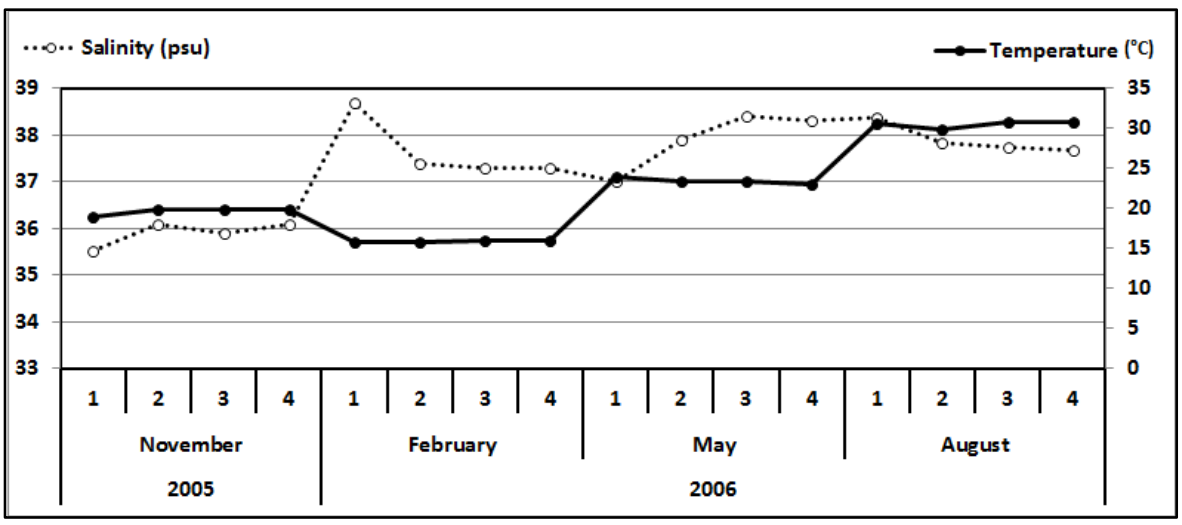

Figure 2. Changes in the surface temperature and salinity values during the sampling periods

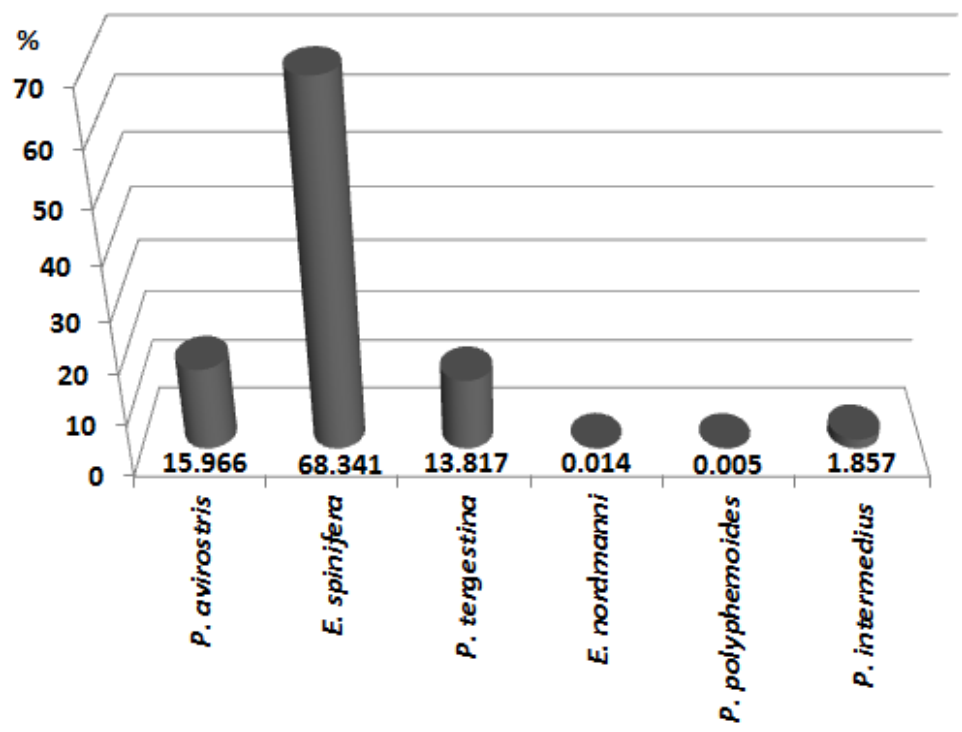

Figure 3. Proportion of the annual mean abundance of cladoceran species 
Total cladoceran abundance showed temporal and spatial variations during the study. The lowest $\left(0.006\right.$ ind. $\left.\mathrm{m}^{-3}\right)$ and the highest (47.93 ind. $\mathrm{m}^{-3}$ ) cladoceran abundance was observed at the offshore station (station, 4) in November-05 and in May-06, respectively (Figure 5). In May-06, higher abundance values were also observed at nearcoastal station (station 1). Especially in August-06 and May-06, significant differences were observed between stations in term of abundance (Figure 5).

Regarding the spatial distribution of cladoceran, there was no notable nearcoastal offshore difference. $P$. intermedius, $P$. polyphemoides and $E$. nordmanni were observed rarely in the study area. However, E. spinifera, $P$. avirostris and $P$. tergestina were the species that mainly affected cladoceran abundance and reached the highest abundance in May-06 (Figure 6). Cladocerans are densely found in the hyponeustonic layer and even over $30 \mathrm{~cm}$ depth (Moraitou-Apostolopoulou and Kiortsis 1973). P. avirostris, E. spinifera and $P$. tergestina are typical warm-water species (Onbè 1999; Marazzo and Valentin 2000). P. avirostris is a eurohaline and neritic species that mostly prefers low salinity waters (Moraitou-Apostolopoulou and Kiortsis 1973, Lakkis,
2011). In our study, this species was observed during the whole sampling period. P. tergestina has a higher temperature range compared to $E$. spinifera among cladoceran species recorded in this study, (Kiortis and Moraitou-Apostopoulou 1975) and is found proportionately more densely than E. spinifera in August-06 when temperature was highest. On the other hand, E. nordmanni is known to be a coldwater species which is seen rarely in the months with lower temperatures (Onbè et al. 1996) and was observed only in February-06 when temperature was lowest, which is consistent with its ecology. There are contradictory reports about temporal distribution of $P$. polyphemoides. Onbè (1999) and Della Croce and Venugopal (1972) defined this is as a warm-water species. On the other hand, Büyükateş and İnanmaz (2007) stated that this species showed negative correlation with temperature. In addition, Kiortis and Moraitou-Apostopoulou (1975) reported that its distribution was limited with January-March. This species was recorded in spring (cold period) and summer (warmer period) in İskenderun Bay by Terbıyık Kurt and Polat (2014). In present study, we similarly observed it in February-06 when the temperature is lower.

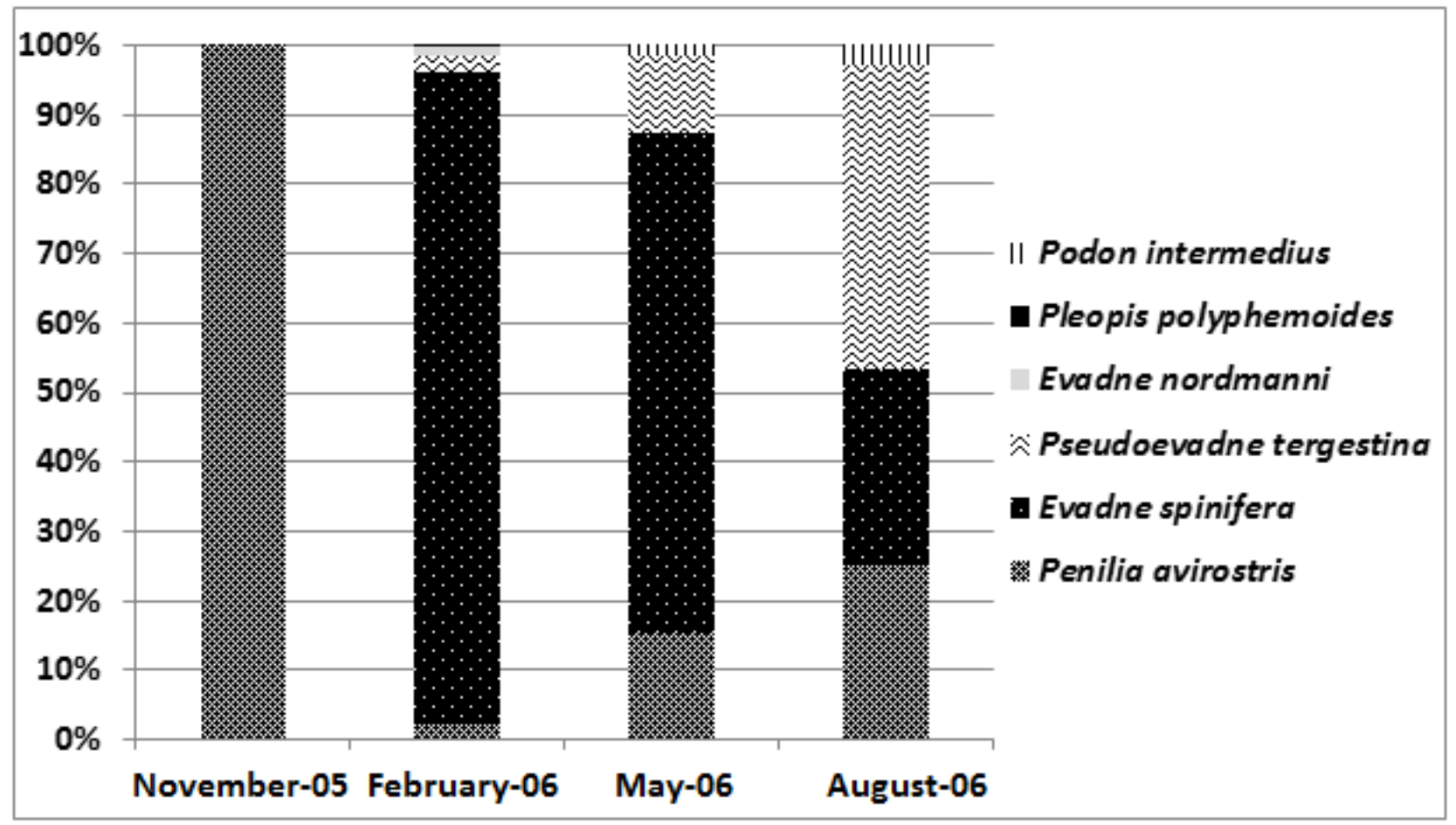

Figure 4. Availability of cladoceran species in percentage in the months when the study was conducted 

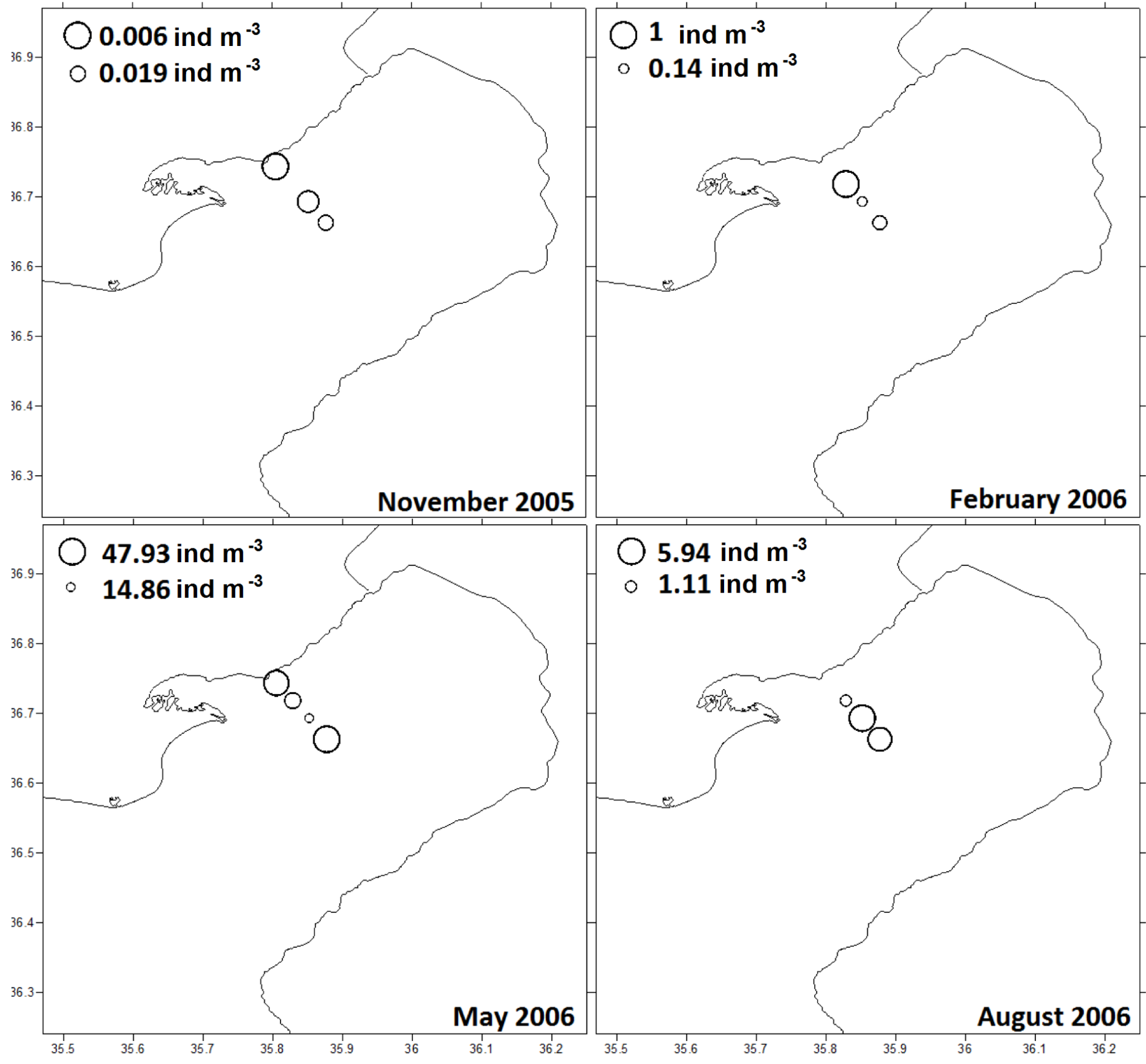

Figure 5. Monthly and spatial changes in the total abundance values of cladocerans 


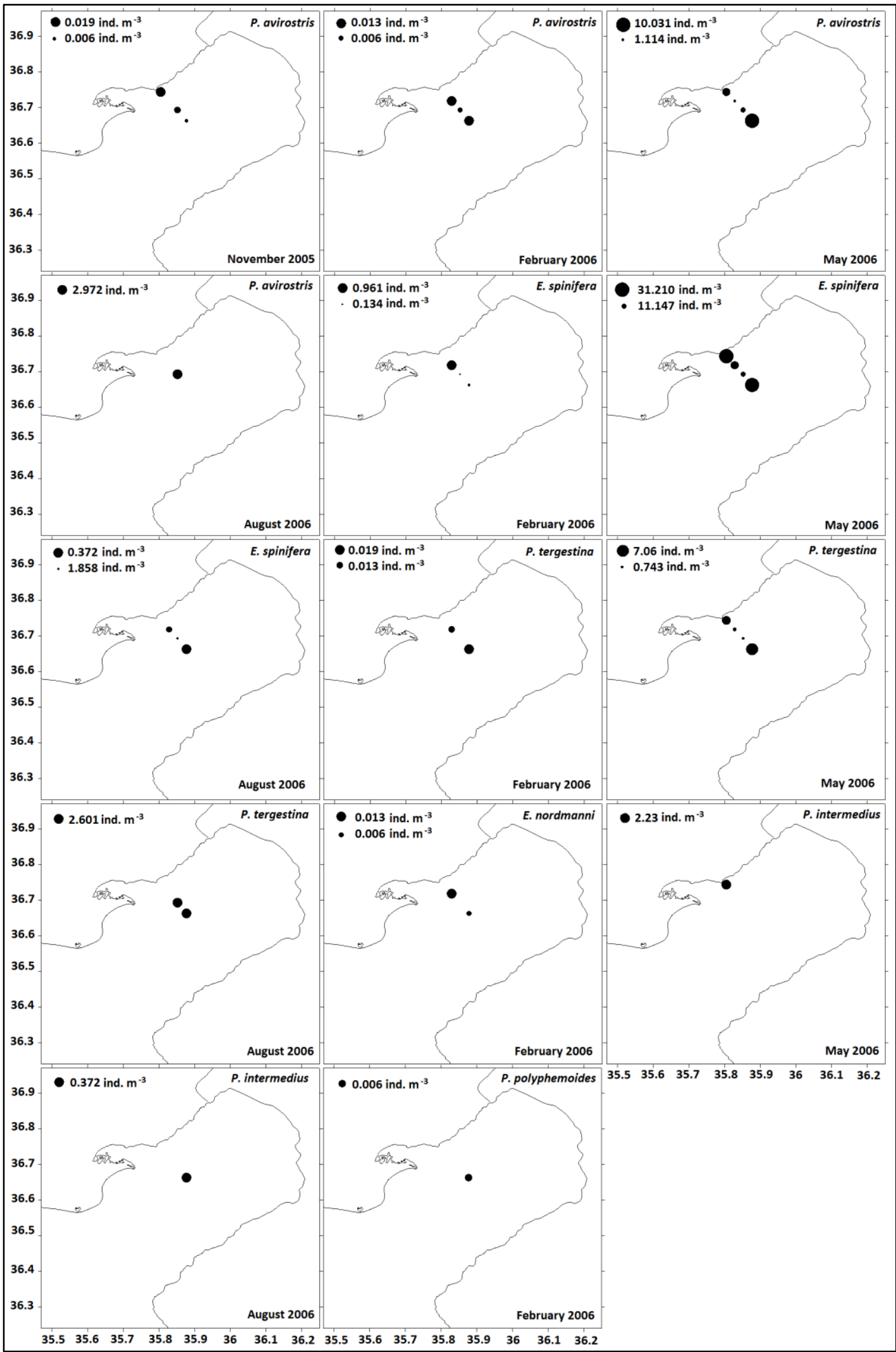

Figure 6. Monthly and spatial changes in the abundance values of cladoceran species 
The abundance of cladocerans is much lower in surface area of İskenderun Bay when compared to other studies conducted in the same area (Terbiy1k Kurt and Polat, 2013, 2014, 2017). However, it should be taken into account that different sampling methods were used in these studies. Morever, cladocerans were collected by vertical tows and conducted in the area close to coast in these studies (Terbiy1k Kurt and Polat, 2013, 2014, 2017).

In our study, we observed fluctuations in the distribution of cladocerans. The effect of temperature on cladocerans is a well-known phenomenon. However, besides temperature, the availability of food is remarkably important on the distribution. Although the temperature in May was lower than August, cladocerans were more abundant, which might be related to the amount of available food or the reproduction period of cladocerans as well as the hydrography of the environment where they were observed. Indeed, it is known that the highest chlorophyll-a concentration was observed in İskenderun Bay in May (Polat and Terbiy1k, 2014). Besides seasonal changes, the changes at the stations might be due to land based inputs, mainly arising from the flow of Ceyhan River and circulation dynamics in the bay. Iskenderun Bay has a hydrographically dynamic structure. On the other hand, the region is remarkably affected by terrestrial pollutants leading from agricultural activities, industrial and domestic wastes. The variable conditions in the bay which is caused by such factors is also affect distribution and abundance characteristics of the organisms.

Several studies on cladocerans were conducted in previous years in the region. Dönmez (1998) observed cladocerans only in summer and spring, while Terbiy1k and Polat (2013) observed them in all seasons except November and reported the existence of four species which were $P$. avirostris, $E$. spinifera, P. tergestina and Podon intermedius. Toklu Alıçlı and Sarihan (2016) encountered cladoceran species in all seasons except winter and reported the existence of four species which were $P$. avirostris, E. spinifera, $P$. tergestina and Pleopis polyphemoides. Moreover, recently, Pleopis schmackeri was recorded in İskenderun Bay by Terbiyı Kurt and Polat (2017). In the present study, E. nordmanni was firstly observed in February 2006 and the number of the cladoceran species in İskenderun Bay raised to seven. The species showed distribution in Western Mediterranean Sea (Sampaio de Souza et al. 2011; Fernandez de Puelles et al. 2003) and various parts of Eastern Mediterranean Sea (Kiortis and Moraitou-Apostopoulou 1975; Siokou Frangou 1996; Brautovic 2001). This species is also distributed in Turkish coastal waters of the Black Sea (Demir 1955), Marmara Sea (Demir 1955; Büyükateș and İnanmaz 2007) and
Aegean Sea (Aker and Özel 2006; Tarkan 2000). It is thought that the species had not been recorded before due to the scarcity or more local studies conducted in Iskenderun Bay and the rare presence of the species.

\section{Conclusions}

In this study, the abundance changes, composition and distribution of cladocerans which is a important group in pelagic ecosystems were analyzed in surface waters of Iskenderun Bay. The results of this study showed that there were clear seasonal changes in the distribution and abundance of cladocera species of the İskenderun Bay. The findings of this study might serve as a reference for future studies. In this respect, studies to be conducted in wider areas with more frequent sampling periods will be beneficial to determine changes in cladoceran population.

\section{Acknowledgements}

We thank Levent Itri Erkol for helping us during the sampling processes.

\section{References}

Aker, V., Özel, İ. (2006). İzmir Körfezi Kladoserlerinde Mevsimsel Dağılım. Ege Üniversitesi Su Ürünleri Dergisi, 23(1/1), 17-22.

Avşar, D. (1999). Yeni Bir Skifomedüz (Rhopilema nomadica)' ün Dağılımı ile ilgili Olarak Doğu Akdeniz'in Fiziko-Kimyasal Özellikleri. Turkish Journal of Zoology, 23(2), 605-616.

Bosch, H.F., Taylor, W.R. (1968). Marine cladocerans in the Chesapeake Bay Estuary. Crustaceana, 15, 161-164.

Bosch, H.F., Taylor, W.R. (1973). Distribution of the cladoceran Podon polyphemoides in Chesapeake Bay. Marine Biology, 19, 161-171.

Brautovic, I. (2001). Annual distribution of cladocerans in the open sea near Dubrovnik (South Adriatic). Rapport Commission International pour l'Exploration Scientifique de la Mer Méditerranée, 36, 247.

Büyükateş, Y., İnanmaz, Ö.E. (2007). Temporal Variations in Vertical Distrubution and Occurence of Marine Cladocerans in an Urbanized Harbour, Dardanelles, Turkey. Crustaceana, 80(11), 1293-1302.

Büyükateş, Y., İnanmaz, Ö.E. (2010). The Annual Mesozooplankton Dynamics and Influence of Environmental 
Parameters in an Urbanized Harbor (Kepez HarborDardanelles Strait, Turkey). Ekoloji, 19, 74, 60-68.

Della Croce, N., Venupogal, P. (1972). Distribution of marine cladocerans in the Indian Ocean. Marine Biology, $15,132-138$.

Demir, M. (1955). Copepods (Cladocera) and their species found in Marmara Sea and coastal waters of the Black Sea. Ístanbul Üniversitesi Fen Fakültesi Hidrobiyoloji Araştırma Enstitüsü, 3(1),37-49.

Dönmez, A. (1998). İskenderun Körfezi’ nin Botaş (Yumurtalık) ve Arsuz (İskenderun) Arası Kıyı alanında Copepoda ve Cladocera (Crustacea) Gruplarına ait Zooplanktonik Organizmaların Dikey Dağılımı ve mevsimsel değişimi, Master thesis. Çukurova University.

Ferna'ndez de Puelles, M.L., Gras, D., Hernàndez de Leon, S. (2003). Annual cycle of zooplankton, biomass, abundance and species composition in the neritic area of the Balearic Sea, Western Mediterranean. Marine Ecology, 24(2), 1-17.

Gieskes, W.W.C. (1971). Ecology of the Cladocera of the North Atlantic and the North Sea, 1960-1967. Netherlands Journal of Sea Research, 5, 342-376.

İyiduvar, O. 1986. Hydrographic characteristics of Iskendeun Bay. Masters Thesis, Icel. Middle East Technical University, Institute of Marine Sciences, Turkey.

Kiortis, V. Moraitou-Apostopoulou, M. (1975). Marine Cladocera (Crustacea) in the eutrophicated and polluted Saronic Gulf (Greece), Israel Journal of Zoology, 24, 71-74.

Lakkis, S. (2011). Le Zooplancton Marin du Liban (Méditerranée Orientale), Biologie, Biodiversité, Biogéographie. Beyrouth: Publications de l'Université Libanaise, p. 1-568, ISBN 978-88-548-6334-7

Marazzo, A., Valentin, J.L. (2000). Daily variation of marine cladoceran densities in a tropical bay-Brazil. $\mathrm{Hy}$ drobiologia, 428(1), 205-208.

Moraitou-Apostolopoulou, M., Kiortsis, V. (1973). The cladocerans of the Aegean Sea: Occurrence and seasonal Variation. Marine Biology, 20,137-143.
Onbè, T. (1999). Ctenopoda and Onychopoda (=Cladocera). In: D. Boltovskoy (Ed.), South Atlantic Zooplankton (p. 797-811). Leiden, Brachuys Publishers. ISBN: 9057820358

Onbè, T., Tanimura, A., Fukuchi, M., Hattori, H., Sasaki, H., Matsuda, O. (1996). Distribution of marine cladocerans in northern Bering Sea and Chukci Sea. Proceedings of the NIPR Symposium on Polar Biology, 9, 141152.

Polat, S., Terbiyik, T. (2013). Variations of Planktonic Chlorophyll-a in Relation to Environmental Factors in a Mediterranean Coastal System (Iskenderun Bay, Northeastern Mediterranean Sea). Sains Malaysiana, 42(10), 1493-1499.

Sampaio de Souza, C.S., Mafalda JR,P., Sallěs, S., Ramirez, T., Cortěs, D., Garcia, A., Mercado, J., Vargas-Yaňez, M. (2011). Seasonal changes in the distribution and abundance of marine cladocerans of the Northwest Alboran Sea (Western Mediterranean). Brazilian Archives of Biology and Technology, 54(3), 543-550.

Sherman, K. (1966). Seasonal and areal distribution of zooplankton in coastal waters of Gulf of Maine, 1964. US Fish and Wildlife Service, Special Scientific ReportFisheries 530, 1-11.

Siokou-Frangou, I. (1996). Zooplankton annual cycle in a Mediterranean coastal area. Journal of Plankton Research 18(2), 203-223.

Tarkan, A. N. (2000). Abundance and distribution of zooplankton in coastal area of Gökçeada Island (Northern Aegean Sea). Turkish Journal of Marine Sciences, 6 (3), 201-214.

Terbıyık Kurt, T., Polat, S., (2014). Characterization of seasonal and inter-annual changes in the abundance of species of marine Cladocera on the Turkish coast of the northeastern Levantine Basin. Crustaceana, 87(7), 769-783.

Terbiyık Kurt, T., Polat, S. (2017). Introduction of a new Indo-Pacific marine cladoceran to the Mediterranean Sea. Mediterranean Marine Science, DOI: $\underline{10.12681 / \mathrm{mms} .13885}$ 
Terbıyık Kurt, T., Polat, S. (2013). Seasonal Distribution of Coastal Mesozooplankton Community in Relation to the Environmental Factors in Iskenderun Bay (Northeast Levantine, Mediterranean Sea), Journal of the Marine Biological Association of the United Kingdom, 93(5), 1163-1174.

Toklu, B., Sarıhan, E. (2003). The Copepoda and Cladocera (Crustacea) Fauna Along the Yumurtal1k-Botas Coastline in Iskenderun Bay. E.ge Üniversitesi Su Ürünleri Dergisi. 20, 63-68.
Toklu-Alıçlı, B., Sarıhan, E. (2016). Seasonal Changes of Zooplankton Species and Groups Composition in Iskenderun Bay (North East Levantine, Mediterranean Sea). Pakistan Journal of Zoology, 48(5), 1395-1405.

Tregouboff, G. (1963). La distribution verticale des cladoceres au large de Villefranche-sur-Mer. Bulletin de I'Institut Oceanographique Monaco, 61, 1279, 1-23. 